\title{
Joint field experiments for comparisons of measuring methods of photosynthetic production*
}

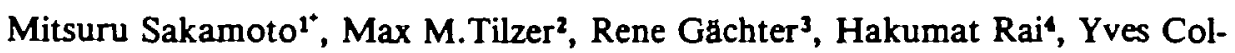
$\operatorname{los}^{5}$, Pierre Tschumi ${ }^{6}$, P.Berner, D.Zbaren ${ }^{6}$, J.Zbaren $^{6}$, Martin Dokulil', Peter Bossard ${ }^{3}$, Urs Uehlinger ${ }^{3}$ and Ernst A.Nusch

${ }^{1}$ Water Research Institute, Nagoya University, Nagoya 464, Japan, 2 Limnological Institute, University of Konstanz, D-7750, Konstanz, FRG, ${ }^{3}$ Swiss Federal Institute for Water Resources and Water Pollution Control, CH-6047 Kastanienbaum, Switzerland, ${ }^{4}$ Max-Planck-Institute for Limnology, 232 Plon, FRG, 'Station Marine d'Endoume, Laboratoire d'Oceanographie, Campus de Luminy Case 902, 13288 Marseille, C9, France, 'Department of Zoology, University of Bern, CH-3012 Bern, Switzerland, 'Institute for Limnology, Gaisberg 116, A-5310 Mondsee, Austria, and 'Chemical and Biological Laboratory, Ruhrverband, 4300 Essen 1, FRG.

(Received August 1983; accepted December 1983)

Abstract. During the 1st GAP Workshop at Konstanz in April 1982 comparative measurements of phytoplankton primary production by several techniques were conducted simultaneously at an offshore station in Lake Konstanz and an experimental algal pond. Suspended glass bottle exposure techniques using ${ }^{14} \mathrm{C}$ and ${ }^{13} \mathrm{C}$ uptake gave $P_{2}\left(\mathrm{mg} \mathrm{C} \mathrm{m}^{-1} \mathrm{~h}^{-1}\right)$ values which varied considerably nearsurface, but estimates of areal rates for the euphotic zone $\Sigma P_{a u}\left(\mathrm{mg} \mathrm{C} \mathrm{m} \mathrm{m}^{-1} \mathrm{~h}^{-1}\right)$ which were reasonably close. In the lake, $\Sigma P_{z}$ from a vertical tube exposure (with ${ }^{14} \mathrm{C}$ uptake) was greater than rates derived for integrated bottle samples. The oxygen bottle method permitted a good estimate of compensation depth, corresponding to in situ growth studies. There were difficulties in direct comparison between $\mathrm{O}_{2}$ and carbon methods. Correlation between them for $P_{2}$ was good in the lake but poor in the pond, both for suspended bottle and vertical tube methods. This series demonstrates that despite reasonable overall estimates, comparatively minor methodological differences in experimental technique can cause large variation.

\section{Introduction}

Phytoplankton photosynthesis is a fundamental process in aquatic environments and quantitative information on primary production in a given water body is essential to understanding ecosystem metabolism and the dynamics of phytoplankton populations. The main techniques for quantifying primary production have remained the light and dark oxygen bottle method (Gaarder and Gran, 1927) and the ${ }^{14} \mathrm{C}$ method (Steemann Nielsen, 1952). Each of these has advantages for certain aquatic environments, but the interpretation of results and an evaluation of their physiological and ecological importance is often difficult. This situation frequently hampers comparison and further analysis of data derived by different

\footnotetext{
+ Coordinator of the group for comparative measurements of photosynthetic production at the GAP Workshop, Konstanz, April 1982.
}

-This paper is the result of a study made at the Group for Aquatic Primary Productivity (GAP) First International Workshop held at the Limnological Institute, University of Konstanz, in April 1982. 
methods and researchers (Strickland, 1960; Vollenweider, 1974; Fogg, 1975; Harris, 1980; Peterson, 1980).

Recent advances in understanding the biophysics and biochemistry of photosynthesis have also led to further examination of implications of data obtained by routine methods in natural environments (Harris and Piccinin, 1977; Sheldon and Sutcliffe, 1978; Peterson, 1980; Platt, 1980).

The purpose of the joint field experiments, which were conducted during the GAP Workshop at Konstanz, was to compare several methods for measuring phytoplankton photosynthesis and to assess their reliability and limitations in primary production studies. Most participants in these experiments used their own apparatus and techniques.

\section{Experimental locations and materials}

The experiments were conducted at two locations on 21 April 1982; a station about $500 \mathrm{~m}$ off the northeastern coast of Lake Konstanz, and an experimental pond at the Limnological Institute, University of Konstanz. The depth of the lake station was $80 \mathrm{~m}$ and the Secchi disk reading was $4.5 \mathrm{~m}$. Due to cold and stormy weather which prevailed for some days before the start of experiments, the lake water was well mixed vertically with only a slight decrease of water temperature with depth in the euphotic zone (Table I). The dominant phytoplankton were Rhodomonas lens, $R$. minuta, Asterionella formosa, Stephanodiscus hantzschii and $\mu$-algae (Heaney and Sommer, 1984). Chlorophyll $a$ concentration, determined spectrophotometrically in hot-ethanol (Marker et al., 1980) and corrected for phaeophytin (Lorenzen, 1967), and dissolved inorganic carbon (DIC) measured by alkalinity titration (Găchter et al., 1984) were almost uniform throughout the euphotic zone (Table I). The $1 \%$ depth of the surface irradiance, $I_{0}$, assumed to correspond roughly to the daily compensation depth, was $12.5 \mathrm{~m}$ (Jewson et al., 1984).

In the experimental pond, phytoplankton biomass was $14.4 \mathrm{~mm}^{3}$ cell volume $1^{-1}$ and chlorophyll $a$ concentration was $12.5 \mathrm{mg} \mathrm{Chl} a \mathrm{~m}^{-3}$ (corrected for phaeopigments) about seven times higher than that in the lake. The phytoplankton was dominated by Chlamydomonas, which accounted for $94.3 \%$ of total algal biomass. Photosynthetically available radiation (PAR) at the bottom of the pond (depth $1.1 \mathrm{~m}$ ) was $51 \%$ of $I_{0}$ and DIC concentration was $9.86 \mathrm{~g} \mathrm{C} \mathrm{m}^{-3}$.

The lake samples were collected with a $91 \mathrm{PVC}$ Van-Dorn sampler on board the RV Robert Lauterborn, from 0, 1, 2, 3, 5, 8, 10 and $15 \mathrm{~m}$ depths. Each sample was transferred into a large plastic bottle (20 I), and after thorough mixing, dispensed into experimental bottles in diffused dim light in the ship's cabin. At the pond, an integrated water column sample down to $1 \mathrm{~m}$ depth was taken with a plexiglass tube, mixed well in a carboy and distributed into experimental bottles in the laboratory.

\section{Methods}

\section{Types of exposure experiments}

Two types of experimental enclosures, glass bottles and vertical perspex tubes, 
Table 1. Lake Konstanz: physico-chemical and biological background data at the experimental station on 21 April 1982.

\begin{tabular}{|c|c|c|c|c|c|c|c|}
\hline \multirow{2}{*}{$\begin{array}{l}\text { Water } \\
\text { depth } \\
\text { (m) }\end{array}$} & \multirow{2}{*}{$\begin{array}{l}\text { Water } \\
\text { temp. } \\
\left({ }^{\circ} \mathrm{C}\right)\end{array}$} & \multirow{2}{*}{\multicolumn{2}{|c|}{$\begin{array}{l}\text { Photosynthetically } \\
\text { available radiation }\end{array}$}} & \multicolumn{2}{|c|}{ Chlorophyll $\sigma^{2}$} & \multirow{2}{*}{$\begin{array}{l}\text { Phytoplankton } \\
\text { cell volume } \\
\left(\mathrm{mm}^{3} \mathrm{~m}^{-1}\right)\end{array}$} & \multirow{2}{*}{$\begin{array}{l}\text { Dissolved } \\
\text { inorganic } \\
\text { carbon } \\
\left(\mathrm{g} \mathrm{m}^{-3}\right)\end{array}$} \\
\hline & & & (\%) & $\begin{array}{l}\text { uncorrected } \\
\left(\mathrm{mg} \mathrm{m} \mathrm{m}^{-3}\right)\end{array}$ & $\begin{array}{l}\text { corrected }^{d} \\
\left(\mathrm{mg} \mathrm{m}^{-3}\right)\end{array}$ & & \\
\hline 0 & 5.9 & 1247 & 100 & 2.47 & 1.76 & 211 & 30.9 \\
\hline 1 & 5.9 & 756 & 60.0 & 2.60 & 1.90 & 258 & 30.5 \\
\hline 2 & 5.8 & 459 & 36.8 & 2.56 & 1.87 & 375 & 30.4 \\
\hline 3 & 5.8 & 307 & 24.6 & 2.42 & 1.78 & 329 & 30.3 \\
\hline 4 & 5.8 & 205 & 16.4 & - & - & - & - \\
\hline 5 & 5.7 & 143 & 10.8 & 2.50 & 1.83 & 273 & 29.7 \\
\hline 8 & 5.6 & 51 & 4.1 & 2.31 & 1.69 & 182 & 31.0 \\
\hline 10 & 5.6 & 26 & 2.1 & 2.25 & 1.64 & 154 & 29.7 \\
\hline 12 & 5.6 & 14 & 1.14 & - & - & - & - \\
\hline 15 & 5.6 & 5.7 & 0.46 & 1.93 & 1.40 & 161 & 29.8 \\
\hline 18 & 5.6 & 2.4 & 0.19 & - & - & - & - \\
\hline$\Sigma_{\overline{\mathbf{x}}}$ & & & & $\begin{array}{r}34.69 \\
2.31\end{array}$ & $\begin{array}{r}25.36 \\
1.69\end{array}$ & $\begin{array}{r}3310 \\
221\end{array}$ & \\
\hline
\end{tabular}

Measured by the staff at Limnological Institute, Konstanz.

bRecorded by Jewson et al. (1983).

'Enumerated by U. Sommer.

dCorrected for phacopigments.

Table II. Size and number of glass bottles used for exposure experiments at each exposure depth in two locations. For experimental type, see text.

\begin{tabular}{|c|c|c|c|c|c|c|}
\hline \multirow{2}{*}{$\begin{array}{l}\text { Experimental } \\
\text { type }\end{array}$} & \multirow[t]{2}{*}{ Experimenter } & \multirow{2}{*}{$\begin{array}{l}\text { Size } \\
(\mathrm{ml})\end{array}$} & \multicolumn{3}{|l|}{ Number } & \multirow{2}{*}{$\begin{array}{l}\text { Experimental } \\
\text { locations }\end{array}$} \\
\hline & & & light bottles & dark bottles & O-time blanks & \\
\hline 1 (i) & Tilzer & 120 & 2 & 1 & - & lake and pond \\
\hline 1 (ii) & Gachter and Mares & 120 & 2 & 1 & $1^{\star}$ & lake and pond \\
\hline 1 (iii) & Rai & 570 & 2 & 1 & - & lake \\
\hline 1 (iv) & Collos ${ }^{b}$ & 2000 & 1 & 0 & $I^{c}$ & lake \\
\hline 1 (iv) & Sakamoto & 570 & 2 & 1 & $1^{d}$ & lake and pond \\
\hline $1(v)$ & Tschumi et al. & 120 & 3 & 3 & 3 & lake \\
\hline $1(v)$ & Dokulil & 120 & 2 & $5^{e}$ & $4^{d}$ & pond \\
\hline
\end{tabular}

Only for the lake sample.

bFor simulated in situ exposure, the same size and number of bottles were employed at each light level. For the samples at $0 \mathrm{~m}$ and $10 \mathrm{~m}$ depth.

${ }^{d}$ For one integrated sample in the pond, but for each depth sample in the lake.

'All dark bottles were incubated at a middle depth.

were used for in situ exposures in both lake and pond. Table II shows the size and number of the glass bottles used for these experiments. Details of the vertical perspex tube enclosures are described below.

Eight types of exposure experiments were run in parallel at both locations to estimate photosynthetic rates at each depth, $P_{2}$, and areal integral photosynthetic rates $\Sigma P_{z}$. (The investigators responsible for each method are also indicated below.) 
Experiment 1 . In situ exposure in suspended glass bottles. Lake water from different depths was incubated in situ. In the pond, samples from an integrated water column were exposed at $0,0.15,0.3,0.5$ and $1.0 \mathrm{~m}$.

(i) Tilzer: Incubation with added ${ }^{14} \mathrm{C}$-bicarbonate, followed by filtration on $0.8 \mu \mathrm{m}$ membrane filters. $P_{\mathbf{z}}$ was calculated from ${ }^{14} \mathrm{C}$ uptake values, total activity of added ${ }^{14} \mathrm{C}$, and DIC concentration of lake waters (Gáchter et al., 1984).

(ii) Gächter and Mares: Subsamples were withdrawn from the same bottles used in Experiment (i) after incubation. The unfiltered samples were acidified, bubbled with air to remove inorganic ${ }^{14} \mathrm{C}$, and their radioactivities determined. The activity of dissolved organic carbon in filtrates from parallel samples was also measured (Gächter et al., 1984).

(iii) Rai: Lake samples from 0,2 and $15 \mathrm{~m}$ of the lake were incubated with ${ }^{14} \mathrm{C}$ bicarbonate, then filtered through 106, 35 and $10 \mu \mathrm{m}$ Nytal screens, respectively. Duplicate portions from these filtrations as well as from an unfiltered sample were subsequently passed through $0.2 \mu \mathrm{m}$ membrane filters and the contribution of each size fraction on total $P_{2}$ was estimated (Rai, 1982).

(iv) Collos and Sakamoto: The ${ }^{13} \mathrm{C}$ method (Slawyk et al., 1977; 1979) was used to measure $\boldsymbol{P}_{\mathbf{z}}$.

Collos: The working isotope solution was a ${ }^{13} \mathrm{C}$ bicarbonate solution $(3 \mathrm{mg} \mathrm{C}$ $\left.1^{-1}\right)$ prepared from $\mathrm{Ba}^{13} \mathrm{CO}_{3}$ (90.1 atom \%: CEA, Service des Molecules Marques, France), sterilized and stored in a $250 \mathrm{ml}$ Teflon bottle. Each 21 lake sample was incubated in situ with $6 \mathrm{ml}$ of the isotope solution, and then filtered on Whatman GF/C glassfiber filters (47 mm diameter) under reduced vacuum $\left(<100 \mathrm{~mm} \mathrm{Hg}\right.$ ). The filters were dried at $60^{\circ} \mathrm{C}$ and stored in a desiccator. Isotope analysis was carried out with a MS-10 mass spectrometer (Ass. Elect. Ind.) using each half of the filters. Particulate carbon of the lake water was determined with a Perkin-Elmer $240 \mathrm{C}$ elementary analyser on $100 \mathrm{ml}$ samples which were passed through Whatman GF/C filters (24 mm diameter) and dried at $60^{\circ} \mathrm{C}$.

Sakamoto: $\mathrm{NaH}^{13} \mathrm{CO}_{3}$ (91.8 atom \%: BOC. Ltd., London) was dissolved in glass distilled water, dispensed into pyrex ampoules and sterilized in boiling water. The final inorganic carbon concentration $\left(3.3 \mathrm{mg} \mathrm{C} \mathrm{ml}^{-1}\right)$ and isotope ratio of the working solution were later determined with an infrared $\mathrm{CO}_{2}$ analyser and a mass spectrometer. The water samples incubated with ${ }^{13} \mathrm{C}$ isotope solution and the zero time blank samples, taken just after an addition of isotope solution, were filtered onto preignited Whatman GF/C filters $(24 \mathrm{~mm}$ diameter). The filters were dried, and particulate carbon content and isotope ratio were simultaneously determined with a small quadrupole mass spectrometer (Anelva, TE-150) coupled with an automatic elementary analyser (Yanagimoto, MT-2) after Otsuki et al. (1983).

$P_{z}$ values were calculated similarly by Collos and Sakamoto from the atom $\%$ excess ${ }^{13} \mathrm{C}$ of filter samples, the atom $\%$ excess ${ }^{13} \mathrm{C}$ of the inorganic carbon pool, DIC, and particulate carbon concentration of the samples (Slawyk et al., 1979).

(v) Tschumi et al. and Dokulil: In both the lake and the pond, light and dark bottles were incubated in situ to measure changes in dissolved oxygen, DO. For the lake experiments, Tschumi et al. employed an improved oxygen technique with a precision of $2-5 \mu \mathrm{g} \mathrm{O}_{2} 1^{-1}$ (Tschumi et al., 1978), and in the pond series, 
Dokulil used the back-titration and amperometric endpoint detection technique (Talling, 1973).

Experiment 2. Simulated in situ exposure experiment. Collos: Pyrex glassbottles (2l) were wrapped in neutral density nickel screens to give $60,38,21,10,6$ and $2 \%$ of $I_{0}$ and filled with the lake water from the corresponding depths. After addition of ${ }^{13} \mathrm{C}$ solution, the bottles were placed in a water-cooled incubator on the Institute pier close to the lake station. Subsequent processing and analysis were as in Collos, Experiment 1(iv).

Experiment 3. In situ exposure in vertical perspex tubes. (i) Bossard and Uehlinger: Transparent plexiglass tubes ( $2 \mathrm{~m}$ length, $19 \mathrm{~mm}$ diameter), which can be linked together to give any desired length, were used for exposures. A thin silicon hose (1.3 $\mathrm{mm}$ inner diameter) of the same length as the exposure tube was filled with $\mathrm{NaH}^{14} \mathrm{CO}_{2}$ solution $\left(9 \mu \mathrm{Ci} \mathrm{ml}{ }^{-1}\right)$, and inserted with its base at the bottom end of the exposure tube prior to the start of experiment. After the whole system was placed vertically in the water column, a device at the bottom-end closed the tube bottom and also broke a glass tip at the base of the silicon hose (Figure 1). Homogeneous spiking of ${ }^{14} \mathrm{C}$ solution throughout the enclosed water

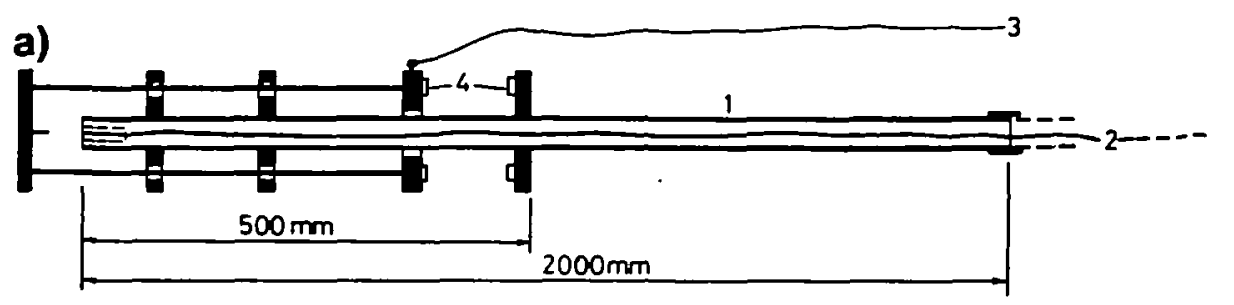

b)

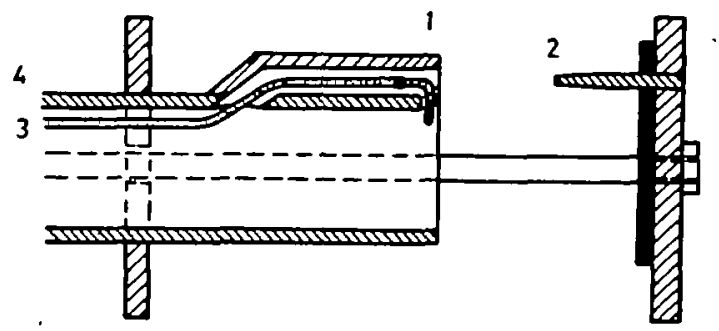

c)

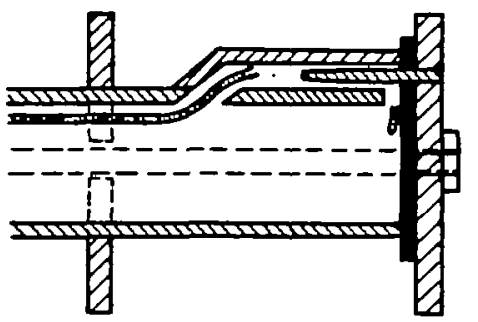

Fr. 1. Exposure tube (Bossard and Uehlinger) showing closure and release of ${ }^{44} \mathrm{C}(\mathrm{a})$ General view of exposure tube. (1) Tube; (2) Silicon hose; (3) Closing twine; (4) Magnets. (b) Tube as lowered into water in open position. (1) Tube wall; (2) Tube bottom with pin; (3) Silicon hose containing ${ }^{14} \mathrm{C}$ bicarbonate solution with glass tip. (c) Tube after closure and breakage of glass tip. 
Table III. Exposure times and surface irradiance data during the exposure experiments in Lake Konstanz and algal pond on 21 April 1982. Light data are from Jewson et al. (1983).

\begin{tabular}{|c|c|c|c|}
\hline Experimenter & Time & $\begin{array}{l}\operatorname{PAR}\left(I_{0}\right) \\
\text { (Quanta } \mathrm{cm}^{-} \text {) }\end{array}$ & $\begin{array}{l}\text { Average PAR } \\
\left.\text { (aEinstein } \mathrm{m}^{-2} \mathrm{~s}^{-1}\right)\end{array}$ \\
\hline \multicolumn{4}{|l|}{ Lake } \\
\hline Tilzer and Gachter & $08.50-12.51$ & $1.21 \times 10^{21}$ & 1386 \\
\hline Rai & $08.55-12.55$ & $1.15 \times 10^{2 n}$ & 1326 \\
\hline Sakamoto & $09.15-13.15$ & $1.16 \times 10^{n}$ & 1342 \\
\hline Collos & $09.25-13.25$ & $1.18 \times 10^{22}$ & 1362 \\
\hline Tschumi et al. & $09.30-13.30$ & $1.18 \times 10^{22}$ & 1360 \\
\hline \multicolumn{4}{|l|}{ Pond } \\
\hline Tilzer, Guchter & $10.32-14.32$ & & \\
\hline $\begin{array}{l}\text { and Dokulil } \\
\text { Sakamoto }\end{array}$ & $10.40-15.00$ & & \\
\hline
\end{tabular}

column was accomplished by pulling the thin hose upwards through a squeezing mechanism located at the upper end of the exposure tube. Final activity in the exposure tube was about $40 \mu \mathrm{Ci}^{-1}$. After light exposure, the contents of the tube were transferred into 51 glass bottles, and the ${ }^{14} \mathrm{C}$ uptake was measured in subsamples by acid-bubbling and scintillation counting as in Experiment 1(ii).

(ii) Nusch: A vertical water column was enclosed by lowering transparent and darkened plexiglass tubes ( 1 or $2.5 \mathrm{~m}$ length, $40 \mathrm{~mm}$ inner diameter) into the water and incubated with or without vertical circulation by pump as described in Nusch (1981). Dissolved oxygen in the tube was measured with an oxygen probe (Chemtronic Waltemode OX653) installed in a measuring cell through which the incubated water passed. $P_{\mathbf{z}}$ and $\Sigma P_{\mathbf{z}}$ were estimated from differences in oxygen probe reading before and after exposure (Nusch, 1981), and, on some subsamples, by Winkler titration.

\section{Mooring and exposure of the enclosed samples}

At the lake station, five buoys were connected to each other at $3 \mathrm{~m}$ intervals with ropes, and bottles were suspended on lines from the center of each buoy so as to minimize shading effects. Four of the buoys were constructed of two floats connected by a long metal rod, one buoy was made of a triangle of plastic tubes. In the pond, sample bottles were hung from a long steel pole which crossed the pond, or were fixed at desired depths on a vertical stand. Tube samples were held vertically by special buoyant frames of transparent plexiglass (Nusch, 1981).

\section{Exposure times and light conditions}

The exposure times and $I_{0}$ during the experiments are given in Table III. Although there were some differences in light environment, these should not have been large enough to cause any significant changes in production rates between experiments.

Isotopic and chemical analysis of experimental samples and data work up

After the termination of exposure, all subsequent work up of samples (fil- 
Tabte IV. Lake Konstanz: photosynthetic rates $P_{2},\left(\mathrm{mg} \mathrm{C} \mathrm{m}^{-3} \mathrm{~h}-1\right.$, or $\mathrm{mg} \mathrm{O}_{2} \mathrm{~m}^{-3} \mathrm{~h}-$ ) determined in situ by suspended bottle methods.

\begin{tabular}{|c|c|c|c|c|c|c|c|}
\hline \multirow{2}{*}{$\begin{array}{l}\text { Depth } \\
\text { (m) }\end{array}$} & \multicolumn{5}{|c|}{$P_{Z}\left(\mathrm{mg} \mathrm{Cm}^{-3} \mathrm{~m}^{-1}\right)$} & \multirow{2}{*}{\multicolumn{2}{|c|}{$\underset{\text { Tschumi }}{P_{Z}\left(\mathrm{mg} \mathrm{O}_{2} \mathrm{~m}^{-3}-\mathrm{T}\right.}$}} \\
\hline & Tilzer & Gachter & Rai & Collos & Sakamoto & & \\
\hline 0 & 1.03 & 1.2 & 1.35 & 1.6 & 3.3 & -2.2 & -22.1 \\
\hline 1 & 4.08 & 5.1 & 3.91 & 5.1 & 7.6 & 9.4 & 1.8 \\
\hline 2 & 3.82 & 6.2 & 4.48 & 3.2 & 3.8 & 14.4 & 9.5 \\
\hline 3 & 3.45 & 5.3 & - & 3.6 & - & 18.2 & 12.5 \\
\hline 5 & 3.27 & 3.2 & - & 4.9 & 2.6 & 14.2 & 9.7 \\
\hline 8 & 2.13 & 3.1 & - & 2.1 & 1.4 & 5.4 & -1.1 \\
\hline 10 & 1.12 & 1.3 & - & - & - & 0.1 & -6.8 \\
\hline 15 & 0.25 & 0.5 & 0.48 & 0.6 & 0.3 & -7.6 & -9.7 \\
\hline Method & $\begin{array}{l}{ }^{14} \mathrm{C} \\
\text { filtered } \\
\text { samples }\end{array}$ & $\begin{array}{l}{ }^{14} \mathrm{C} \\
\text { acid- } \\
\text { bubbling }\end{array}$ & $\begin{array}{l}{ }^{14} \mathrm{C} \\
\text { filtered } \\
\text { samples }\end{array}$ & $\begin{array}{l}{ }^{12} \mathrm{C} \\
\text { mass- } \\
\text { spectro- } \\
\text { metry }\end{array}$ & $\begin{array}{l}\text { i2C } \\
\text { mass- } \\
\text { spectro- } \\
\text { metry }\end{array}$ & $\begin{array}{l}\text { precise } \\
\text { titration }\end{array}$ & metric \\
\hline
\end{tabular}

GP: Gross production

bNP: Net production

Table V. Algal Pond: photosynthetic rates $P_{Z},\left(\mathrm{mg} \mathrm{Cm}^{-3} \mathrm{~h}^{-1}\right.$, or $\left.\mathrm{mg} \mathrm{O}_{2} \mathrm{~m}^{-3} \mathrm{~h}^{-1}\right)$ determined in situ by suspended bottle methods ( $\mathrm{Chl} a$ content $12.5 \mathrm{mg} \mathrm{m}^{-3}$, dissolved inorganic carbon $9.86 \mathrm{~g} \mathrm{C} \mathrm{m}^{-3}$ ).

\begin{tabular}{|c|c|c|c|c|c|c|}
\hline \multirow{2}{*}{$\begin{array}{l}\text { Depth } \\
\text { (m) }\end{array}$} & \multirow{2}{*}{$\begin{array}{l}\text { PAR } \\
\text { (\%) }\end{array}$} & \multicolumn{3}{|c|}{$P_{\mathrm{Z}}\left(\mathrm{mg} \mathrm{O}_{2} \mathrm{~m}^{-3} \mathrm{~h}^{-1}\right)$} & \multirow{2}{*}{\multicolumn{2}{|c|}{$\begin{array}{c}P_{\mathrm{Z}}\left(\mathrm{mg} \mathrm{O}_{\mathbf{2}} \mathrm{m}^{-1} \mathrm{~h}^{-1}\right) \\
\text { Dokulil }\end{array}$}} \\
\hline & & Tilzer & Gachter & Sakamoto & & \\
\hline 0 & 100 & 2.4 & 4.1 & 4.5 & 150 & 140 \\
\hline 0.15 & 87 & 3.5 & 4.7 & 4.9 & 70 & 60 \\
\hline 0.30 & 77 & 3.5 & 5.3 & 5.2 & 60 & 50 \\
\hline 0.50 & 68 & 4.7 & 6.5 & 5.6 & so & 40 \\
\hline 1.00 & 53 & 5.3 & 7.7 & 6.1 & so & 40 \\
\hline Method & & $\begin{array}{l}{ }^{14} \mathrm{C} \\
\text { fultered } \\
\text { samples }\end{array}$ & $\begin{array}{l}{ }^{24} \mathrm{C} \\
\text { acid } \\
\text { bubbling }\end{array}$ & $\begin{array}{l}{ }^{2} \mathrm{C} \\
\text { mass- } \\
\text { spectro- } \\
\text { metry }\end{array}$ & $\begin{array}{r}0 \\
\text { amperon } \\
\text { end poin } \\
\text { detection }\end{array}$ & \\
\hline
\end{tabular}

tration, isotope and chemical analysis etc.) were done immediately at the Institute laboratory in order to permit initial evaluation by the GAP Workshop participants. ( ${ }^{13} \mathrm{C}$ mass spectrometric analyses were an exception to this.)

\section{Results and Discussion}

The photosynthetic rates measured by suspended bottle methods in the lake and the experimental algal pond are shown in Tables IV and V. For replicated samples, the mean value at each depth was tabulated. $P_{z}$ values from the ${ }^{12} \mathrm{C}$ method were calculated by multiplying specific uptake rates, $V_{c}$, by particulate carbon concentrations (Table VI). Five vertical profiles of photosynthetic rates measured in situ at the lake were substantially similar (Figure 2), although differences were found in the depths of maximum activity, $P_{\max }$, especially between 


\section{M.Sakamoto et al.}

Table V. Lake Konstanz: Specific carbon uptake rates $(V c)^{n}$ determined in situ by ${ }^{27} \mathrm{C}$ methods, and particulate carbon concentration.

\begin{tabular}{|c|c|c|c|c|}
\hline \multirow[t]{2}{*}{$\begin{array}{l}\text { Depth } \\
\text { (m) }\end{array}$} & \multicolumn{2}{|l|}{$\begin{array}{l}V \mathrm{c} \\
\left(\mathrm{h}^{-1}\right)\end{array}$} & \multicolumn{2}{|c|}{$\begin{array}{l}\text { Particulate carbon } \\
\left(\mathrm{gC}^{-1}\right)\end{array}$} \\
\hline & Collos & Sakamoto & Collos & Sakamoto \\
\hline 0 & 0.003 & 0.007 & 0.46 & 0.45 \\
\hline 1 & 0.010 & 0.017 & 0.47 & 0.44 \\
\hline 2 & 0.007 & 0.008 & 0.45 & 0.45 \\
\hline 3 & 0.010 & - & 0.37 & - \\
\hline 5 & 0.010 & 0.007 & 0.50 & 0.40 \\
\hline 8 & 0.005 & 0.004 & 0.39 & 0.31 \\
\hline 15 & 0.003 & 0.001 & 0.25 & 0.25 \\
\hline
\end{tabular}

2Calculated from the atom excess $50{ }^{12} \mathrm{C}$ for the incubated samples, for the unenriched or zero time blank samples, and for ambient inorganic carbon in the lake water after Slawyk et al. (1979).

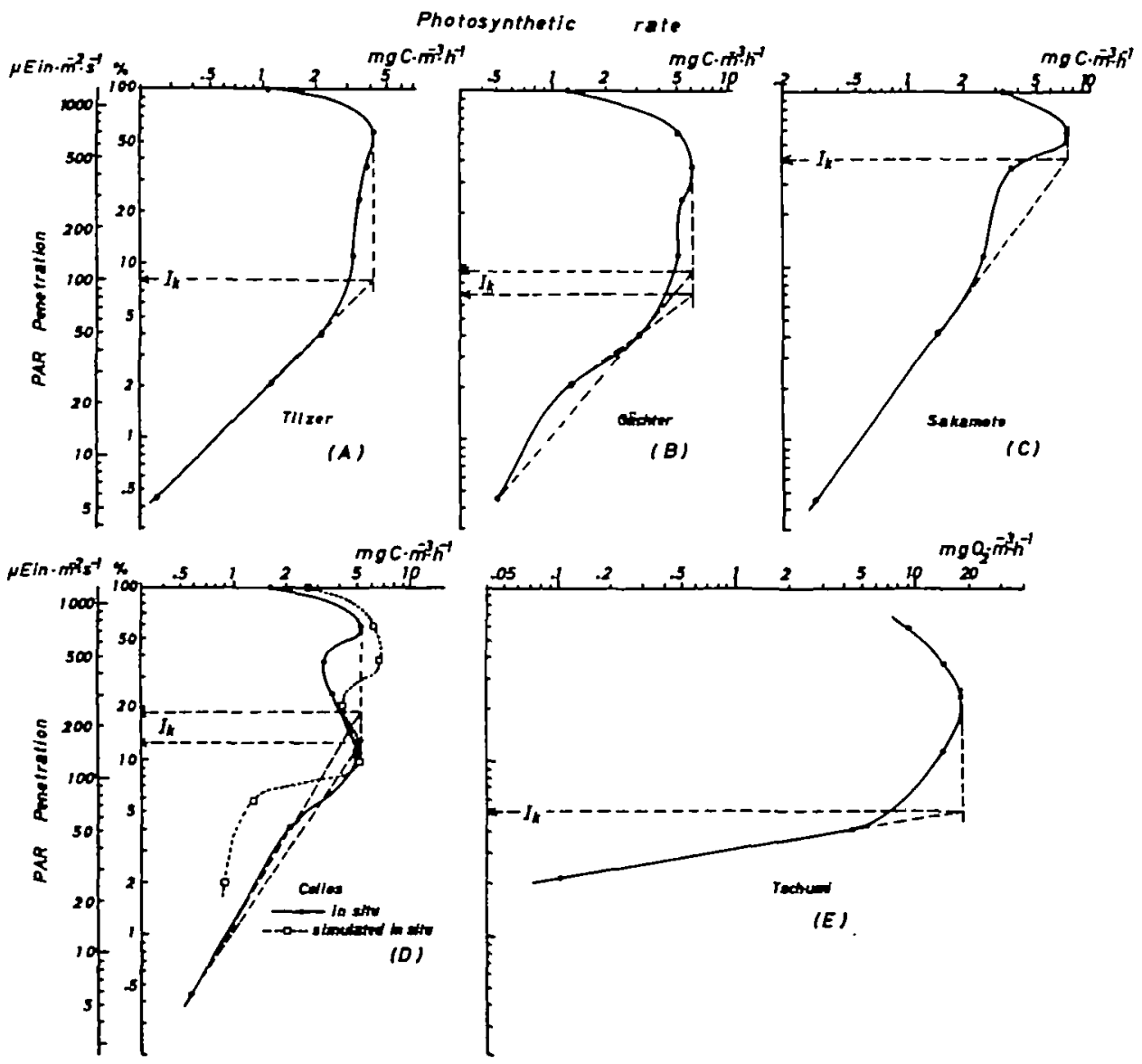

Fig. 2. Lake Konstanz: Profiles of primary productivity and estimated $I_{\mathrm{k}}$ measured by ${ }^{14} \mathrm{C},{ }^{12} \mathrm{C}$ and $\mathrm{O}_{2}$ methods with in situ bottle incubation. (Note: the oxygen profile is based on gross photosynthetic measurements.) The sampling depths indicated are $0,1,2,3,5,7,10$ and $15 \mathrm{~m}$. 


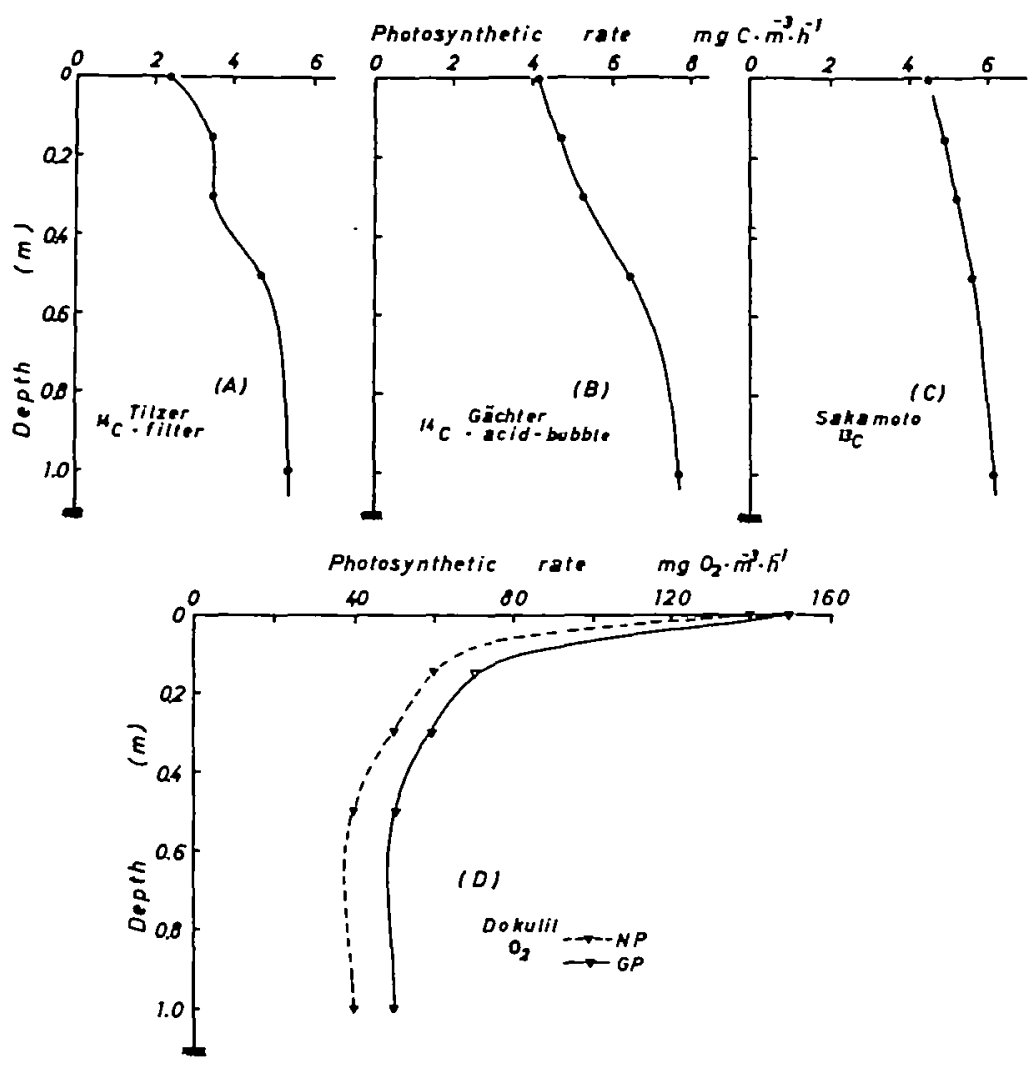

Fig. 3. Algal pond: profiles of primary production from ${ }^{14} \mathrm{C},{ }^{12} \mathrm{C}$ and oxygen methods.

the carbon uptake $\left({ }^{14} \mathrm{C}\right.$ and ${ }^{13} \mathrm{C}$ ) and DO methods.

$P_{\mathrm{z}}$ values given by the simulated in situ exposure with ${ }^{13} \mathrm{C}$ technique (Collos) converted to equivalent light depths are also shown in Figure 2. The main discrepancy between the in situ and simulated results was the depth of $P_{\max }$.

At the pond, the profile derived from the oxygen bottle method was remarkably different from that given by ${ }^{13} \mathrm{C}$ and ${ }^{14} \mathrm{C}$ methods (Figure 3). All the isotope techniques gave $P_{\max }$ at the lowest depth in contrast to the surface maximum found with the oxygen method.

There was considerable variation for $P_{z}$ values given by different ${ }^{14} \mathrm{C}$ and ${ }^{13} \mathrm{C}$ methods. In the lake, the greatest variation was noted at 0 and $1 \mathrm{~m}$, (coefficient of variation c.v. $=\sigma 100 / \mathrm{x}), 70.8$ and $65.4 \%$ respectively and lower c.v. $(10.7-34.8 \%)$ for depths below $2 \mathrm{~m}$. Similar variations were observed at the pond where the c.v. was $30.3 \%$ at the surface and $16.1-19.2 \%$ at the depths below $0.15 \mathrm{~m}$.

Several reasons may be suggested for these variations. One cause could be the inconsistency of corrections for dark uptake and isotope discrimination used by different experimenters. In Experiment 1(i) and 1(iii), dark $C$ uptake values were subtracted from light values at each depth, and also a correction for isotope dis- 
crimination was applied, but in the other isotope experiments these corrections were not used. According to Gachter et al. (1983), dark uptake ranged from $8-17 \%$ of the light values in Experiments $1(i)$ and $1(i i)$ at the pond where the whole water column was under saturating insolation. In the ${ }^{13} \mathrm{C}$ experiments by Sakamoto in the lake, dark uptake was $1-2 \%$ of the light values near the surface and $5-9 \%$ at deeper layers: in the pond, dark uptake was $1.2-1.6 \%$. Thus, inaccuracies in this correction factor might explain some discrepancies in the deeper $P_{z}$ values but would have little effect on near surface estimates. The isotope discrimination factor proposed by Fisher et al. (1979), is smaller than the factor of 1.06 used here in Experiments 1(i), and 1(iii). No correction for isotope discrimination was applied for the present ${ }^{13} \mathrm{C}$ results but it is unlikely that this would explain the observed differences between ${ }^{14} \mathrm{C}$ and ${ }^{13} \mathrm{C}$ methods.

The variation between duplicate samples in any one single experiment was low. The relative deviation of $P_{z}$ values to their mean was $<12 \%$ on the results from Experiment 1(i), $<16 \%$ on Experiment 1(ii) and $<5 \%$ on Experiment 1(iii). Although the systematic errors in ${ }^{14} \mathrm{C}$ productivity work should not exceed $5 \%$ with careful blank control, standardization of ${ }^{14} \mathrm{C}$ working solution, and the correct evaluation of ambient DIC (Strickland, 1960), some differences of experimental manipulation may produce systematic errors with a c.v. up to $10 \%$ (Doty and Oguri, 1958). Even with a single technique, the c.v. may reach $-20 \%$ between measurements from successive samples (Doty et al., 1965). This indicates that the variation found in the results between different experiments in this series was well within the systematic error to be expected in field work.

Maske (1984) examined the effect of ultraviolet radiation on photosynthetic carbon assimilation in these experiments and showed that ${ }^{14} \mathrm{C}$ uptake could increase because of protection from short wave length radiation when glass vessels were used as incubation enclosures. Similar results have been reported by Jitts et al. (1976) and Lorenzen (1979). The glass bottles used in our experiments were different in size (Table II) and came from various manufacturers. Some of the observed differences between experiments especially at higher irradiance, may have been due to such 'bottle effects'.

The range in experimental bottle size may also have led to initial differences in the enclosed plankton assemblages (e.g. in the numbers of zooplankton) and a subsequent heterogeneity of phytoplankton populations during incubation (Sheldon et al., 1973; Venrick et al., 1977).

Further causes of variations in $P_{\mathrm{z}}$ values between experiments can be suggested and should be carefully evaluated in future. In the ${ }^{14} \mathrm{C}$ methods, errors could arise in the standardization of ${ }^{14} \mathrm{C}$ working solution (Iverson et al., 1976), because of heavy metal contamination (Carpenter and Lively, 1980), and in the quench correction factors used. Difference in the kinds of filters employed by each experimenter (membrane filters of $0.8 \mu \mathrm{m}$ pore size in Experiment 1(i), of $0.2 \mu \mathrm{m}$ in Experiments 1(ii) and 1(iii), and glass fiber filters of $-1.0 \mu \mathrm{m}$ in Experiment 1(iv)) could have affected the relative amounts of retained particulate and filtrate ${ }^{14} \mathrm{C}$. Gachter et al. (1984) detected a negligibly small release of labelled dissolved organic matter in $0.2 \mu \mathrm{m}$ filtrates. 'Filtrate' losses would be expected to be higher from $0.8 \mu \mathrm{m}$ and $1.0 \mu \mathrm{m}$ filters leading to underestimations of the particulate 
Table VII. Lake Konstanz: vertical changes of the Photosynthetic Quotient (PQ). Determined from oxygen production rates (Tschumi) and carbon uptake rates (filtered samples, Tilzer, and acid bubbling method, Gachter and Marts using ${ }^{14} \mathrm{C}$ technique).

\begin{tabular}{lll}
\hline $\begin{array}{l}\text { Depth } \\
\text { (m) }\end{array}$ & PQ & \\
\hline 1 & filtered & acid-bubbled \\
2 & 0.87 & 0.69 \\
3 & 1.41 & 0.87 \\
5 & 1.98 & 1.29 \\
8 & 1.63 & 1.02 \\
mean & 0.95 & 0.63 \\
\hline
\end{tabular}

production rates. In contrast, filter contamination by inorganic and dissolved organic matter would overestimate $P_{z}$ (Arthur and Rigler, 1967; Berman and Eppley, 1974).

A source of error specific to the ${ }^{13} \mathrm{C}$ method is the possibility of incomplete combustion of the samples to $\mathrm{CO}_{2}$ gas for mass spectrometric analysis which would lead to underestimations of the carbon uptake rate. Because of the systematic error involved in sample preparations and mass spectrometric analysis, the estimated $P_{z}$ values at $\leq 1 \mathrm{mg} \mathrm{C} \mathrm{m}^{-3} \mathrm{~h}^{-1}$ are of low reliability (e.g. 8 and $15 \mathrm{~m}$ depths).

There are inherent difficulties in comparing results of $\mathrm{O}_{2}$ methods to those from ${ }^{14} \mathrm{C}$ and ${ }^{13} \mathrm{C}$ because the transformation of oxygen evolution to carbon uptake is not straightforward (McAllister et al., 1964; Harnis and Piccinin, 1977; Harris, 1980). However, if the values obtained by short term (up to 4-5 h) ${ }^{14} \mathrm{C}$ and ${ }^{13} \mathrm{C}$ methods are assumed to be close to gross photosynthesis (Dring and Jewson, 1982), then these may be compared to gross photosynthesis estimated by the $\mathrm{O}_{2}$ method to evaluate the photosynthetic quotient, $\mathrm{PQ}\left(\mathrm{O}_{2} \mathrm{~mol}\right.$ evolved $/ \mathrm{CO}_{2} \mathrm{~mol}$ assimilated). An example for the lake station based on data from Experiments 1(i), 1(ii) and 1(v) (Tschumi) is given in Table VII. The estimated $P Q$ values ranged from $0.80-1.98$ and $0.63-1.29$ for ${ }^{14} \mathrm{C}$ filtered and ${ }^{14} \mathrm{C}$ acid-bubbled methods, respectively. These results emphasize that the $P Q$ values are not constant as has often been assumed, and as Williams et al. (1981) have stressed, will vary under different environmental and physiological conditions.

The net $P_{z}$ as determined by the $\mathrm{O}_{2}$ method should be somewhat underestimated due to the inclusion of respiration of zoopolankton and heterotrophic microorganisms. However, if we assume that this effect was small during our experiments, the daytime compensation depth in the lake would be located at $\sim 8 \mathrm{~m}$ (Table IV), corresponding to $\sim 4.0 \%$ of $I_{0}$ but not at $12.5 \mathrm{~m}\left(1 \% I_{0}\right)$. The shallower compensation depth is compatible with the observations of Heaney and Sommer (1984) who followed the quantitative changes in phytoplankton biomass in the lake water samples (suspended in situ) during the joint field experiments and found only a very small increase in total cell volume at $7 \mathrm{~m}$ over $76 \mathrm{~h}$.

Specific photosynthetic rates, $p_{\mathrm{z}}^{\mathrm{B}}\left(\mathrm{mg} \mathrm{C} \mathrm{mg} \mathrm{Chl} a^{-1} \mathrm{~h}^{-1}\right.$ ) in the lake were within the ranges often encountered in mesotrophic lakes (Table VIII) but $P_{z}^{B}$ values in the pond were surprisingly low despite the eutrophic appearance of the 
Table VIII. Lake Konstanz: specific photosynthetic rates $P_{2}^{\mathrm{p}},\left(\mathrm{mg} \mathrm{C} \mathrm{mg} \mathrm{Chl} a^{-1} \mathrm{~h}^{-1}\right.$ or $\mathrm{mg} \mathrm{O} \mathrm{O}_{2} \mathrm{mg}$ Chl $a^{-1} h^{-1}$ ) determined in situ by suspended bottle methods.

\begin{tabular}{|c|c|c|c|c|c|c|c|}
\hline \multirow{3}{*}{$\begin{array}{l}\text { Depth } \\
\text { (m) }\end{array}$} & \multicolumn{5}{|c|}{ (mg C mg Chl $a^{-1} h^{-1}$ ) } & \multirow{2}{*}{\multicolumn{2}{|c|}{$\begin{array}{c}\left(\mathrm{mg} \mathrm{O}_{2} \mathrm{mg} \mathrm{Chl} a^{-1} \mathrm{~h}^{-1}\right) \\
\text { Tschumi }\end{array}$}} \\
\hline & \multirow[t]{2}{*}{ Tilzet } & \multirow[t]{2}{*}{ Gachter } & \multirow[t]{2}{*}{$\mathbf{R a j}$} & \multirow[t]{2}{*}{ Collos } & \multirow[t]{2}{*}{ Sakamoto } & & \\
\hline & & & & & & GP & NP \\
\hline 0 & 0.58 & 0.68 & 0.77 & 0.91 & 1.87 & -1.22 & -12.56 \\
\hline 1 & 2.17 & 2.68 & 2.06 & 2.68 & 3.68 & 4.93 & 0.95 \\
\hline 2 & 2.04 & 3.32 & 2.40 & 1.71 & 2.03 & 7.67 & 5.09 \\
\hline 3 & 1.94 & 2.98 & - & 2.02 & - & 10.20 & 7.02 \\
\hline 5 & 1.78 & 2.84 & - & 2.68 & 1.42 & 7.75 & 5.27 \\
\hline 8 & 1.24 & 1.83 & - & 1.24 & 0.83 & 3.18 & -0.66 \\
\hline 10 & 0.68 & 0.79 & - & - & - & 0.01 & -4.16 \\
\hline 15 & 0.18 & 0.36 & 0.34 & 0.43 & 0.21 & -5.39 & -6.89 \\
\hline
\end{tabular}

Table IX. Algal Pond: specific photosynthetic rates $P_{\mathrm{Z}}^{\mathrm{B}}$, (mg C mg Chl $a^{-1} \mathrm{~h}^{-1}$ or $\mathrm{mg} \mathrm{O} \mathrm{O}_{2} \mathrm{mg} \mathrm{Chl} a^{-1}$ $\left.\mathrm{h}^{-}\right)$determined in situ by suspended bottle methods.

\begin{tabular}{lllllr}
$\begin{array}{l}\text { Depth } \\
\text { (m) }\end{array}$ & \multicolumn{2}{l}{$\begin{array}{l}\left.\text { (mg } \mathrm{mg} \mathrm{Chl} a^{-1} \mathrm{~h}^{-1}\right) \\
\text { Tilzer }\end{array}$} & Gachter & Sakamoto & \multicolumn{2}{l}{$\begin{array}{l}\left.\text { (mg } \mathrm{O}_{2} \mathrm{mg} \mathrm{Chl} a^{-1} \mathrm{~h}^{-1}\right) \\
\text { Dokulil }\end{array}$} \\
\hline 0 & & & & & $\mathrm{NP}$ \\
0.15 & 0.19 & 0.33 & 0.36 & 12.0 & 11.2 \\
0.30 & 0.28 & 0.38 & 0.39 & 5.6 & 4.8 \\
0.50 & 0.28 & 0.42 & 0.42 & 4.8 & 4.0 \\
1.00 & 0.38 & 0.52 & 0.45 & 4.0 & 3.2 \\
\hline
\end{tabular}

green water (Table IX). The pond samples had a low concentration of nutrients $\left(\mathrm{PO}_{4}-\mathrm{P}<5 \mu \mathrm{g} \mathrm{I}^{-1}\right.$, total- $\left.0.3 \mathrm{mg} \mathrm{l}^{-1}\right)$, and the phytoplankton population which had peaked a few days prior to the experiment was probably in a senescent stage.

Areal production rates (obtained by integration of $P_{2}$ down to indicated depths) are given in Tables $\mathrm{X}$ and $\mathrm{XI}$ for the lake and pond, respectively. In the lake $\Sigma P_{z}$ values derived from ${ }^{14} \mathrm{C}$ filtration and ${ }^{13} \mathrm{C}$ methods were fairly close for the water column deeper than $5 \mathrm{~m}$. The acid-bubbling ${ }^{14} \mathrm{C}$ method (Gächter) gave somewhat higher $\Sigma P_{z}$ values for the deeper part of the water column. The shallower the water column, the greater were the differences in $\Sigma P_{z}$ estimates. Areal rates calculated from $\mathrm{O}_{2}$ experiments were compatible with those obtained with ${ }^{14} \mathrm{C}$ as described later and indicated that, in the lake, net production was $<50 \%$ of gross production in the euphotic zone.

It was of interest to compare $\Sigma P_{z}$ estimated from the suspended bottle methods with those obtained from the tube exposures. The latter techniques are of specific advantage for $\Sigma P_{2}$ because they give a complete integration of the entire water column, and also because they are relatively simple to handle. One disadvantage, however, is that at present such methods are suitable only for comparatively shallow water columns.

The $P_{z}$ values determined in vertical tube exposure followed by the acid-bubbling ${ }^{14} \mathrm{C}$ technique (Experiment 3(i)) and those based on the measurement by 
Table X. Lake Konstanz: areal photosynthetic rates $\Sigma P_{x},\left(\mathrm{mg} \mathrm{C}^{-2} \mathrm{~h}^{-1}\right.$, or $\left.\mathrm{mg} \mathrm{O}_{2} \mathrm{~m}^{-2} \mathrm{~h}^{-1}\right)$ determined in situ by suspended bottle methods.

\begin{tabular}{|c|c|c|c|c|c|c|c|}
\hline \multirow{3}{*}{$\begin{array}{l}\text { Integration } \\
\text { depth } \\
\text { (m) }\end{array}$} & \multicolumn{5}{|c|}{ (mg $\mathrm{Cm}^{-2} \mathrm{~h}^{-1}$ ) } & \multirow{2}{*}{\multicolumn{2}{|c|}{$\begin{array}{c}\left(\mathrm{mg} \mathrm{O}_{2} \mathrm{~m}^{-2} \mathrm{~h}^{-1}\right) \\
\text { Tschumi }\end{array}$}} \\
\hline & Tilzer & Gachter & $\mathrm{Rai}$ & Collos & Sakamoto & & \\
\hline & & & & & & GP & NP \\
\hline \multicolumn{8}{|l|}{ down to } \\
\hline 1 & 2.6 & 3.2 & 2.63 & 3.4 & 5.5 & 3.6 & -10.2 \\
\hline 2 & 6.5 & 8.8 & 6.83 & 7.5 & 11.2 & 15.5 & -4.5 \\
\hline 3 & 10.3 & 11.4 & - & 10.9 & (14.4) & 31.7 & 6.6 \\
\hline 5 & 17.0 & 23.1 & - & 19.4 & 20.2 & 64.1 & 28.7 \\
\hline 8 & 25.1 & 35.5 & - & 29.9 & 26.2 & 93.4 & 41.5 \\
\hline 10 & 28.3 & 39.9 & - & (32.6) & (27.9) & 98.9 & 33.5 \\
\hline 15 & 31.7 & 45.4 & - & 39.4 & 32.1 & 80.3 & -7.7 \\
\hline
\end{tabular}

Table XI. Algal Pond: areal photosynthetic rates $\Sigma P_{\mathrm{y}},\left(\mathrm{mg} \mathrm{C} \mathrm{m}^{-2} \mathrm{~h}^{-1}\right.$, or $\left.\mathrm{mg} \mathrm{O}_{2} \mathrm{~m}^{-2} \mathrm{~h}^{-1}\right)$ deter. mined in situ by suspended bottle methods.

\begin{tabular}{lcccccc}
\hline $\begin{array}{l}\text { Integration } \\
\text { depth } \\
(\mathrm{m})\end{array}$ & \multicolumn{2}{l}{$\begin{array}{l}\left(\mathrm{mg} \mathrm{C} \mathrm{m}^{-2} \mathrm{~h}^{-1}\right) \\
\text { Tilzer }\end{array}$} & Gächter & Sakamoto & & \multicolumn{2}{c}{$\begin{array}{c}\left(\mathrm{mg} \mathrm{O}_{2} \mathrm{~m}^{-2} \mathrm{~h}^{-1}\right) \\
\text { Dokulil }\end{array}$} \\
\hline down to & & & & & & \\
0.15 & 0.44 & 0.64 & 0.71 & 16.5 & 15.0 \\
0.25 & $(0.79)$ & $(1.30)$ & $(1.11)$ & $(23.0)$ & $(25.0)$ \\
0.30 & 0.97 & 1.57 & 1.36 & 26.2 & 30.0 \\
0.50 & 1.79 & 2.53 & 2.44 & 37.2 & 39.0 \\
0.75 & 3.04 & 4.24 & 3.91 & 49.7 & 49.0 \\
1.00 & 4.26 & 6.08 & 5.37 & 62.2 & 59.0 \\
1.10 & $(4.79)$ & $(6.85)$ & $(5.98)$ & $(67.7)$ & $(63.0)$ \\
\hline
\end{tabular}

oxygen electrode or Winkler titration (Experiment 3(ii)) are given in Tables XII and XIII respectively. Compared with the carbon isotope techniques (Tables X and XI), the ${ }^{14} \mathrm{C}$ tube method consistently gave higher $\Sigma P_{z}$ values. Harris and Piccinin (1977) showed that high midday irradiation can depress net photosynthesis measured in bottles in situ by 20 to $80 \%$. The higher $\Sigma P_{z}$ values observed in tube exposures in the lake may be partly due to the ability of the algae to migrate throughout the enclosed water column (Marra, 1978) and may give a better measurement of $\Sigma P_{z}$ than those from suspended bottle experiments.

In the pond, the $\Sigma P_{\mathrm{z}}$ value obtained from the profiled exposure tube was in close agreement with that from the suspended bottle experiment despite some difference of exposure times (Table XIII). Also, the Winkler titration on water circulated in the tubes gave similar estimates to those by DO electrode. However, in the lake, where the changes of $D O$ content during the exposure period were small, $\Sigma P_{\mathrm{z}}$ estimates by DO electrode in the tube exposure were almost four times those measured with the precise suspended oxygen bottle method. This suggests that at present the tube exposure with DO electrode as a sensor is limited in use mainly to high productivity waters.

All the data on the areal production rates in the euphotic zone $\left(\Sigma P_{e \mathrm{eu}}\right)$ are summarized in Table XIV. In the lake, $\Sigma P_{\text {eu }}$ is given (1) for the water column down to 
Table XII. Photosynthetic carbon fixation rates determined in vertical tube exposures using the ${ }^{4} \mathrm{C}$ method (Bossard and Uehlinger). Exposure time was 11:28-15:40 (4.2 h) at the lake and 12:03-17:03 (5 h) at the pond.

\begin{tabular}{lllll}
\hline Location & $\begin{array}{l}\text { Depth } \\
(\mathrm{m})\end{array}$ & $\begin{array}{l}P_{\mathrm{Z}} \\
\left(\mathrm{mg} \mathrm{C} \mathrm{m}^{-3} \mathrm{~h}^{-1}\right)\end{array}$ & $\begin{array}{l}\text { water } \\
\text { column } \\
(\mathrm{m})\end{array}$ & $\begin{array}{l}\Sigma \mathrm{P}_{\mathrm{Z}} \\
\left(\mathrm{mg} \mathrm{m}^{-2} \mathrm{~h}^{-1}\right)\end{array}$ \\
\hline Lake & $0-1$ & 5.7 & down to 1 & 5.7 \\
& $1-2$ & 6.4 & 2 & 12.1 \\
& $2-3$ & 6.5 & 3 & 18.6 \\
& $3-4$ & 9.1 & 4 & 27.7 \\
Pond & $0-0.25$ & 6.4 & down to 0.25 & 1.6 \\
& $0.25-0.50$ & 6.7 & 0.50 & 3.3 \\
& $0.50-0.75$ & 8.0 & 0.75 & 5.3 \\
& $0.75-1.10$ & 10.7 & 1.10 & 8.3 \\
\hline
\end{tabular}

Table XIII. Comparison of areal gross production rates $\left(\mathrm{mg} \mathrm{O}_{2} \mathrm{~m}^{-2} \mathrm{~h}^{-1}\right)$ estimated from the changes of DO content in vertical perspex tubes and in suspended glass bottles in Lake Konstanz and the algal pond on 21 April 1982. Exposure times for the tube and suspended bottle experiments were $9.30-17.00 \mathrm{~h}$ and $10.32-14.32 \mathrm{~h}$ in the pond, and $11.15-45 \mathrm{~h}$ and $9.30-13.30 \mathrm{~h}$ in the lake, respectively.

\begin{tabular}{llcc}
\hline Measured with & Exposure type & $\begin{array}{c}\left(\mathrm{mg} \mathrm{O}_{2} \mathrm{~m}^{-2} \mathrm{~h}^{-1}\right) \\
\text { Lake } 2 \mathrm{~m}^{2}\end{array}$ & Pond $1 \mathrm{~m}^{\mathbf{2}}$ \\
\hline \multirow{2}{*}{ DO electrode } & & \\
\multirow{3}{*}{ Winkler titration } & Vertical tube with discrete profiling & 61 & 65 \\
& Vertical tube with circulation & - & 32 \\
& Vertical tube with discrete profiling & - & $54^{\mathrm{c}}$ \\
& Vertical tube with circulation & $16^{\mathrm{d}}$ & $62^{\mathrm{c}}$ \\
\hline
\end{tabular}

-Depth of water column enclosed in tubes.

'Nusch.

'Nusch and Dokulil.

${ }^{\mathrm{d}}$ Tsuchumi et al.

'Dokulil.

$8 \mathrm{~m}$ i.e., the daytime compensation depth estimated from $\mathrm{O}_{2}$ profiles and (2) down to $15 \mathrm{~m}$, close to the limit of gross production. If we use $P Q=1$ (but see reservations above) the suspended bottle oxygen method gave a gross $\Sigma P_{\text {eu }}$ of 35.0 and $30.1 \mathrm{mg} \mathrm{C} \mathrm{m}-2 \mathrm{~h}^{-1}$ for 8 and $15 \mathrm{~m}$ water columns respectively. At the pond, the calculated values of gross $P_{\text {eu }}$ down to $1.0 \mathrm{~m}$ depth $\left(23.3 \mathrm{mg} \mathrm{C} \mathrm{m} \mathrm{C}^{-2}\right.$ $\mathrm{h}^{-1}$ for suspended bottles and $24.4 \mathrm{mg} \mathrm{C} \mathrm{m}^{-2} \mathrm{~h}^{-1}$ for tube exposures) were considerably higher than those derived from the bottle exposures with ${ }^{14} \mathrm{C}$ and ${ }^{13} \mathrm{C}$ methods (Table XI) or from the ${ }^{14} \mathrm{C}$-tube exposure. Thus, the correlation between oxygen and carbon methods in suspended bottles was reasonable for the lake experiments but poor for the pond. In part, these differences could have been due to the senescent state of the algae in the pond which could cause a large error in our assumed PQ value (see above).

An important algal parameter is $I_{k}$, the light intensity at which an extension from the initial slope of the $P$ versus $I$ curve intersects with the $P_{\max }$ (Talling, 1957). The $I_{k}$ values were estimated graphically for five profiles of $P_{z}$ versus downwelling light penetration (Figure 2). The lowest estimate of $I_{k}$ was $65 \mu$ Eins- 


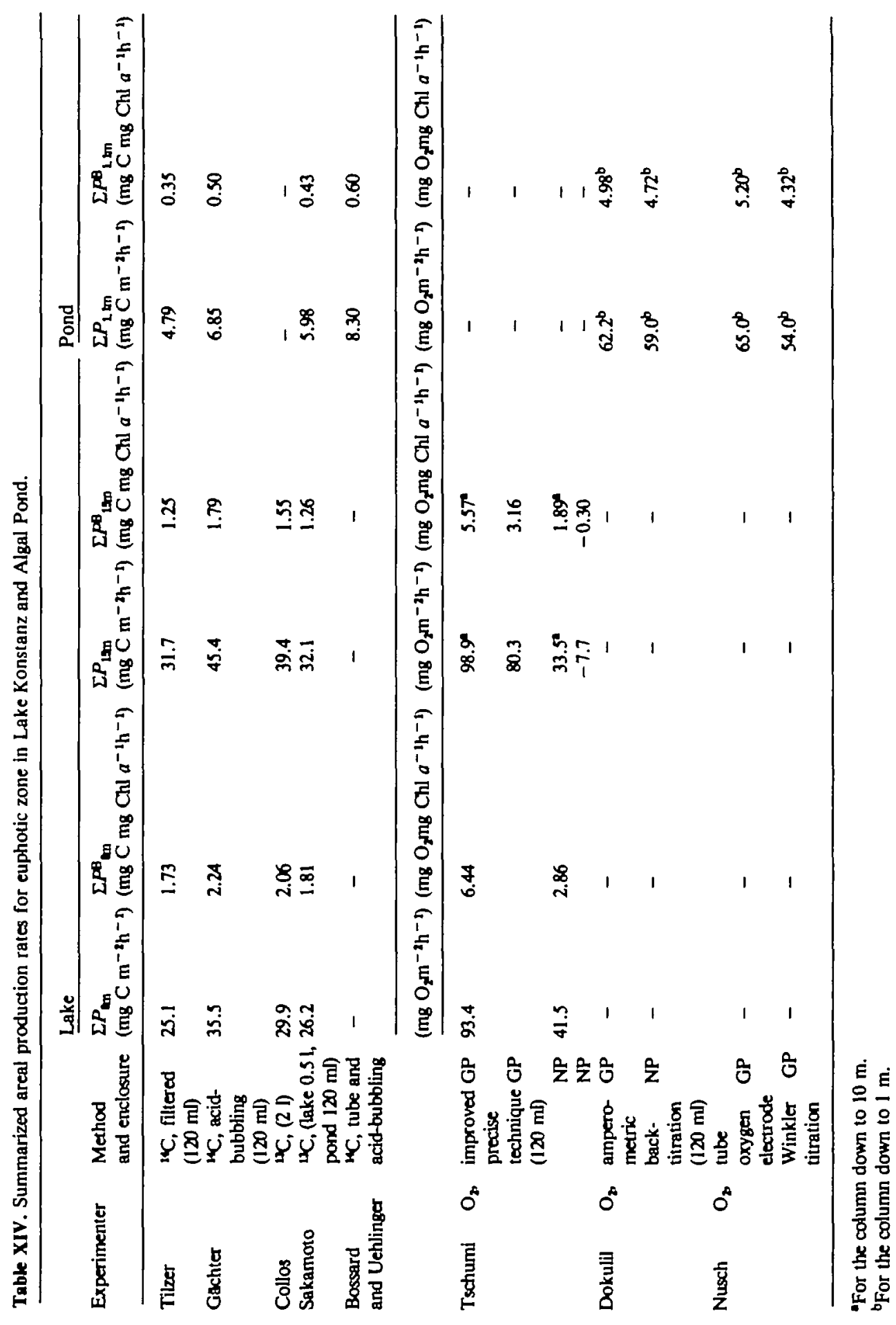


Table XV. Lake Konstanz: contribution of different size fractions in photosynthetic carbon assimilation, as measured with ${ }^{14} \mathrm{C}$ method by $\mathrm{H}$. Rai.

\begin{tabular}{lllr}
\hline $\begin{array}{l}\text { Depth } \\
(\mathrm{m})\end{array}$ & $\begin{array}{l}\text { Size fractions } \\
(\mathrm{m})\end{array}$ & $\begin{array}{l}\text { Carbon assimilation } \\
\left(\mathrm{mg} \mathrm{C} \mathrm{m} \mathrm{m}^{-3} \mathrm{~h}^{-1}\right)\end{array}$ & \% \\
\hline 0 & $<250->106$ & 0.334 & 24.8 \\
& $<106->35$ & 0.094 & 7.0 \\
& $<35->10$ & 0.209 & 15.5 \\
& $<10$ & 0.710 & 52.7 \\
1 & $<250->106$ & 0.677 & 17.3 \\
& $<106->35$ & 0.371 & 9.5 \\
& $<35->10$ & 0.546 & 14.0 \\
& $<10$ & 2.314 & 59.2 \\
2 & $<250->106$ & 0.639 & 14.2 \\
& $<106->35$ & 0.256 & 5.7 \\
& $<35->10$ & 0.643 & 1.0 \\
& $<$ & 3.546 & 79.1 \\
\hline
\end{tabular}

tein $\mathrm{m}^{-2} \mathrm{~s}^{-1}\left(5.2 \% I_{0}\right)$ from the improved oxygen method (Experiment $1(\mathrm{v})$, Tschumi). The ${ }^{14} \mathrm{C}$ methods gave fairly similar $I_{k}, 102 \mu$ Einstein $\mathrm{m}^{-2} \mathrm{~s}^{-1}$ (Experiment 1(i)), $87 \mu$ Einstein $\mathrm{m}^{-2} \mathrm{~s}^{-1}$ or 147 (Experiment 1 (ii)). Higher $I_{k} s$ were obtained from the ${ }^{13} \mathrm{C}$ experiments, 158 or $237 \mu$ Einstein $\mathrm{m}^{-2} \mathrm{~s}^{-1}$ (Collos) and 524 $\mu$ Einstein $\mathrm{m}^{-2} \mathrm{~s}^{-1}$ (Sakamoto).

Some of the above variability is certainly due to the difficulty of determining $I_{k}$ graphically with the available data. Also, there were differences in the handling of the experimental samples, especially in the care which was taken in shielding them from stray or excess light. Attention to methodological details must be emphasized if accurate assessments of parameters such as $I_{\mathbf{k}}$ and compensation depth are to be made.

Important supplementary information was added by the experiment in which ${ }^{14} \mathrm{C}$ photosynthetic fixation by different size fractions of the phytoplankton was measured (Rai, 1982). As has been observed for many other aquatic environments (e.g. Malone, 1980; Kalff, 1972; Pollinger and Berman, 1982), the nanoplankton $(<10 \mu \mathrm{m})$ were the dominant producers in Lake Konstanz at this season (Table XV). Nanoplankton have high metabolic activities and are also the major food organisms for herbivorous zooplankton. For a comprehensive analysis of phytoplankton population dynamics and of ecosystem metabolism, the size partitioning of carbon assimilation is of particular importance. However, to be fully meaningful, this data should be accompanied by a parallel analysis of the biomass composition and growth rate at the species level (see Heaney and Sommer, 1984).

\section{Conclusions}

The GAP Workshop gave us an opportunity to compare several methods for measuring primary productivity in a simultaneous fashion. As we have shown, considerable variation between methods was found for $P_{z}$ which sometime gave very different depth profiles (e.g. Figure 3). Despite this, the estimates by different methods of $\Sigma P_{z}$ were reasonably similar. Techniques which use tube en- 
closures appear to be promising but are limited to shallow water columns. The good correspondence found between ${ }^{14} \mathrm{C}$ and ${ }^{13} \mathrm{C}$ methods was very encouraging especially as the latter technique is less of a health hazard and can be particularly useful in aquatic environments where radioactive isotopes are legally prohibited.

Oxygen methods, especially new modifications which permit high sensitivity and precision, will undoubtedly continue to be widely used. Our experimental series emphasize the difficulties of relating $\mathrm{O}_{2}$ measurements to those based on carbon isotope uptake, particularly with respect to evaluating PQ.

To our knowledge this is the first time that such a wide ranging comparison of field techniques for measuring algal photosynthesis has been made. Although the experiments were limited to two locations on a single day, we suggest that the results obtained are important for an assessment of the reliability (and weakness) of current methodologies for determining aquatic primary production.

\section{Acknowledgements}

The authors thank the following for advice and suggestions: T.Berman, Z.Dubinsky, J.F.Talling, G.P.Harris, T.T.Bannister and P.G.Falkowski. We are grateful to D.Jewson for light data, to U.Sommer for phytoplankton counting and to the staff of the Limnological Institute, University Konstanz for their help during the experiments. Y.Collos thanks Dr. Cahmpeau for elementary analysis of particulate carbon, and Mr. C.Reynaud for technical help and the Centre National de la Recherche Scientifique for financial support (LA 41 and GRECO 130034). M.Sakamoto is indebted to Dr. A.Otsuki for technical advice on mass spectrometric analysis and Yoshida Foundation for Science and Technology for the financial support.

\section{References}

Arthur,C.R. and Rigler,F.M.: 1967, 'A possible source of error in the ${ }^{14} \mathrm{C}$ method of measuring primary productivity', Limnol. Oceanogr., 12, 121-126.

Berman,T. and Eppley,B.W.: 1974, 'The measurement of phytoplankton parameters in nature', Science Prog., 61, 219-241.

Carpenter,E.J. and Lively,J.S.: 1980, 'Review of estimates of algal growth using 14C-tracer techniques', in Falkowski,P. (ed.), Primary Productivity in the Sea, Plenum Press, pp. 161-178.

Doty,M.S., Jitts,H.R., Koblentz-Mishke,O.J. and Saijo, Y.: 1965, 'Intercalibration of marine plankton primary productivity techniques', Limnol. Oceanogr., 10, 282-286.

Doty,M.S. and Oguri,M.: 1958, 'Selected features of the isotopic carbon productivity technique', Rapp. Proc. Verb., Cons. Int. Explor. Mer, 144, 45-55.

Dring,M.J. and Jewson,D.H.: 1982, 'What does i4 C uptake by phytoplankton really measure? A theoretical modelling approach', Proc. $R$. Soc. Lond. B, 214, 351-368.

Dubinsky,Z., Berman, T. and Schanz,F.: 1984, 'Field experiments for in situ measurement of photosynthetic efficiency and quantum yield', J. Plankton Res., 6, 339-349.

Fisher,T.R. Jr., Haines,E.B. and Volk,R.J.: 1979, 'A comment on the calculation of atom percent enrichment for stable isotopes', Limnol. Oceanogr., 24, 593-595.

Fog8,E.G.: 1975, 'Primary productivity', in Riley,J.P. and Skirrow,G. (ed.), Chemical Oceanography, Vol. 2, Academic Press, London, pp. 385-453.

Gaerder,T. and Gran,H.H.: 1927, 'Investigations of the production of plankton in the Oslo Fjord', Rapp. Proc. Verb., Cons. Int. Explor. Mer, 42, 3-48.

Gächter,R., Marks,A. and Tilzer,M.M.: 1984, 'Determination of phytoplankton production by the radiocarbon method: $A$ comparison between the acidification and bubbling method (ABM) and the filtration technique', $J$. Plankton Res., 6, 359-364.

Harris,G.P.: 1980, 'The measurement of photosynthesis in natural populations of phytoplankton', 
in Morris,I. (ed.), The Physiological Ecology of Phytoplankton, Blackwell Scientific, Oxford, pp. 129-185.

Harris, G.P. and Piccinin,B.B.: 1977. 'Photosynthesis by natural phytoplankton populations', Arch. Hydrobiol., 80, 405-457.

Heaney,S.I. and Sommer,U.: 1984, 'Changes of algal biomass as carbon, cell number and volume, in bottles suspended in Lake Constance', J. Plankton Res., 6, 239-247.

Iverson,R.L., Bittaker, H.F. and Myers,U.B.: 1976, 'Loss of radiocarbon in direct use of Aquasol for liquid scintillation counting of solutions containing ${ }^{14} \mathrm{C}-\mathrm{NaHCO}_{3}$, Limnol. Oceanogr., 21, 756-758.

Jewson,D.H., Talling,J.F., Dring,M., Tilzer,M.M., Heaney,S.I. and Cunningham,C.: 1984 'Measurement of photosynthetically available radiation in fresh water: comparative tests of some current instruments used in studies of primary production', J. Plankton Res., 6, 259-273.

Jitts,H.R., Morel,A. and Saijo,Y.: 1976, "The relation of oceanic primary production to available photosynthetic irradiance', Aust. J. Mar. Freshwater Res., 27, 441-454.

Kalff, J.: 1972, 'Net plankton and nannoplankton production and biomass in a north temperate zone lake', Limnol. Oceanogr., 17, 712-720.

Lorenzen,C.J.: 1967, 'Determination of chlorophyll and pheopigments: Spectrometric equations', Limnol. Oceanogr., 12, 343-346.

Lorenzen,C.J.: 1979, 'Ultraviolet radiation and phytoplankton photosynthesis, Limnol. Oceanogr., 24, 1117-1120.

Malone,T.C.: 1980, 'Size fractionated primary productivity of marine phytoplankton', in Falkowski, P.G. (ed.), Primary Productivity in the Sea, Plenum Press, New York, pp. 301-319.

Marker,A.F.H., Nusch,E.A., Raj,H. and Riemann,B.: 1980, 'The measurement of photosynthetic pigments in freshwater and standardization of methods: Conclusions and considerations', Arch. Hydrobiol. Beih. Ergebn. Limnol., 14, 91-106.

Marra,J.: 1978, 'Phytoplankton photosynthetic response to vertical movement in a mixed layer', Mar. Biol., 46, 203-208.

Maske,H.: 1984, 'Day-light ultraviolet radiation and the photo-inhibition of carbon uptake', $J$. Plankton Res., 6, 351-357.

MCAllister,C.D., Shah,N. and Strickland,J.D.H.: 1964, 'Marine phytoplankton photosynthesis as a function of light intensity: A comparison of methods', J. Fish. Res. Bd. Can., 21, 159-181.

Nusch,E.A.: 1981, 'Messung der Chlorophyllfluoreszenz (Kontinuierlich) und der photosynthetischen Sauerstoffproduktion (tiefen ingegriert) in einem entrophen Flupstau', Vom Wasser, 57, 297-308.

Otsuki,A., Ino,Y. and Fujii,T.: 1983, 'Simultancous measurements and determinations of stable carbon and nitrogen isotope ratios, and organic carbon and nitrogen contents in biological samples by coupling of a small quadrupole mass spectrometer and modified carbon-nitrogen elemental analyser', Int. J. Mass Spectrom. Ion Physics, 48, 343-346.

Peterson,B.J.: 1980, 'Aquatic primary productivity and the ${ }^{14} \mathrm{C}-\mathrm{CO}_{2}$ method: A history of the productivity problem', Ann. Rev. Ecol. Syst., 11, 359-385.

Platt, T.: 1980, 'ICES Working Group on primary production methodology', Limnol. Oceanogr., 25, 582.

Pollinger,U. and Berman, T.: 1982, 'Relative contributions of net and nannoplankton to primary production in Lake Kinneret (Israel)', Arch. Hydrobiol., 96, 33-46.

Rai,H.: 1982, 'Primary production of various size fractions of natural phytoplankton communities in a North German lake', Arch. Hydrobiol., 95, 395-412.

Sheldon,R.W., Sutcliffe,W.H. Jr. and Prakash,A.: 1973, 'The production of particles in the surface waters of the oceans with particular reference to the Sargasso Sea', Limnol. Oceanogr., 18, 719-733.

Sheldon.R.W. and Sutcliffe, W.H. Jr.: 1978, 'Generation times of 3h for Sargasso Sea microplankton determined by ATP analysis', Limnol. Oceanogr., 23, 1051-1055.

Slawyk,G., Collos, Y. and Auclair,J.C.: 1977, 'The use of the ${ }^{23} \mathrm{C}$ and ${ }^{4} \mathrm{~N}$ isotopes for the simultaneous measurement of carbon and nitrogen turnover rates in marine phytoplankton', Limnol. Oceanogr., 22, 925-932.

Slawyk,G., Collos,Y. and Auclair,J.C.: 1979, 'Reply to comment by Fisher et al.', Limnol. Oceanogr., 24, 595-597.

Steemann Nielsen, E.: 1952, "The use of radioactive carbon ( $\left.{ }^{14} \mathrm{C}\right)$ for measuring organic production in the sea', J. Cons. Int. Expl. Met, 18, 117-140.

Strickland, J.D.H.: 1960, 'Measuring the production of marine phytoplankton', Bull. Fish. Res. Bd. 
Can., 122, published by Fish. Rs. Bd. Canada.

Talling,J.F.: 1957, 'The phytoplankton populations as a compound photosynthetic system', New Phytol.,56, 133-149.

Talling,J.F.: 1973, 'The application of some electrochemical methods to the measurement of photosynthesis and respiration in fresh waters', Freshwater Biol., 3, 335-362.

Tschumi,P.A., Zbaren,D. and Zbaren, J.: 1978, "An improved oxygen method for measuring primary production in lakes', Verh. Internat. Verein. Limnol., 20, 43-48.

Venrick,E.L., Beers, J.R. and Heinbokel,J.F.: 1977, 'Possible consequences of containing microplankton for physiological rate measurements', J. Exp. Mar. Biol. Ecol., 26, 55-76.

Vollenweider,R.A. (ed.): 1974, 'A Manual on Methods for Measuring Primary Production in Aquatic Environments', IBP Handbook 12, published by Blackwell Scientific, Oxford.

Williams,P.J.LeB., Raine,R.C.T. and Bryan,J.R.: 1981, 'Agreement between the ${ }^{14 C}$ and oxygen method of measuring phytoplankton production. Reassessment of the photosynthetic quotient'. Oceanolog. Acta, 2, 411-416. 